\title{
Board Structures dan Value-Added Intellectual Capital: Studi Kasus pada Industri Barang Konsumsi dan Perdagangan Indonesia
}

\author{
Saarce Elsye Hatane ${ }^{1 *}$, Nadya Gomes I.1, Waisiyana Sastrawati ${ }^{1}$ \\ ${ }^{1}$ Program Studi Akuntansi Bisnis, Fakultas Ekonomi, Universitas Kristen Petra, Surabaya, Indonesia \\ *Penulis korespondensi; Email: elsyehat@petra.ac.id
}

\begin{abstract}
ABSTRAK
Dalam era knowledge-based economy, knowledge-based asset merupakan hal yang penting untuk diinvestigasi. Melalui corporate governance, board of director memiliki tanggung jawab untuk meningkatkan intellectual capital dan mencapai efisiensi maksimum atas penggunaan sumberdaya intellectual capital yang dimiliki, sehingga meningkatkan kinerja keuangan perusahaan. Board structures, sebagai indikator corporate governance, diukur menggunakan the composition of board independence, board size, dan board meeting. Komposisi pendanaan (leverage) dan besarnya assets perusahaan juga menjadi faktor yang mempengaruhi terbentuknya intellectual capital, yang diukur menggunakan Value-Added Intellectual Capital. Objek penelitian ini adalah perusahaan terbuka yang tergabung dalam industri manufaktur barang konsumsi, serta perdagangan. Dari total 112 pengamatan yang dilakukan dari tahun 2010 hingga 2015, dan pengolahan statistik menggunakan analisa regresi berganda, hasil penelitian ini menunjukkan bahwa board meeting dan total assets dapat meningkatkan nilai tambah intellectual capital perusahaan. Berlawanan dengan itu, semakin tingginya komposisi hutang dalam struktur pendanaan dapat menurunkan nilai tambah intellectual capital.
\end{abstract}

Kata kunci: Board Size; Board Independence; Board Meeting; Corporate Governance; Value-Added Intellectual Capital.

\begin{abstract}
In the era of knowledge-based economy, knowledge-based assets is important to be investigated. Through corporate governance, the board of directors has the responsibility to improve the intellectual capital and achieve maximum efficiency on the use of these resources, thus improving the company's financial performance. Board structures, as an indicator of corporate governance, measured using the composition of board independence, board size and board meeting. In addition to a board of directors, the composition of financing (leverage), and the amount of assets are also factors that influence the formation of intellectual capital, which is measured using a Value-Added Intellectual Capital. The objects of this study are public companies incorporated in consumer goods manufacturing industries, and in the trade industry. From a total of 112 observations made from 2010 to 2015, and statistical processing using multiple regression analysis, the results of this study indicate that the board meeting and the total assets may increase the value-added intellectual capital of the company. Contrary to that, the higher the composition of debt in the capital structure can reduce the value-added intellectual capital.
\end{abstract}

Keywords: Board Size; Board Independence; Board Meeting; Corporate Governance; ValueAdded Intellectual Capital.

\section{PENDAHULUAN}

Sistem corporate governance berkembang selama beberapa dekade karena adanya kegagalan yang dialami oleh perusahaan (The Indonesia Corporate Governance Manual, 2014). Skandal akuntansi besar yang dilakukan oleh beberapa perusahaan terkemuka di dunia menyebabkan kegagalan dan kejatuhan perusahaan-perusahaan tersebut. Hal ini menyebabkan publik mulai menaruh perhatiannya pada corporate governance (Kajananthan, 2012). Untuk di Asia sendiri, keter- 
tarikan akan corporate governance dimulai pada tahun 1997 ketika terjadi krisis keuangan yang besar (Reddy, 2009). Krisis yang dialami Indonesia pada tahun 1997 hingga 1998 merupakan salah satu penyebab lemahnya implementasi corporate governance di perusahaan Indonesia. Pemerintah Indonesia pun mengambil suatu langkah inisiatif dengan membentuk Komite Nasional mengenai Kebijakan Corporate Governance (KNKCG) untuk pertama kalinya pada tahun 1999. KNKCG kemudian mengeluarkan Pedoman Umum Corporate Governance Indonesia pada tahun yang sama. Diharapkan dengan adanya corporate governance, krisis keuangan tahun 1997 tidak terulang kembali (The Indonesia Corporate Governance Manual, 2014). Corporate governance kembali berkontribusi dalam krisis keuangan global 2008. Haspeslagh (2010) berpendapat bahwa corporate governance merupakan salah satu faktor penyebab krisis keuangan global 2008. Krisis yang terjadi membuktikan bahwa corporate governance yang ada pada waktu itu tidak cukup baik untuk menghindari perusahaan dari krisis masa depan (Kirkpatrick, 2009).

Corporate governance yang baik adalah bahwa managers memiliki intensi untuk bekerja atas nama shareholders, dan shareholders harus diberitahu tentang semua aktivitas yang dikerjakan oleh managers (Tarraf, 2011). Dengan adanya mekanisme corporate governance akan membantu untuk meningkatkan transparansi sebuah perusahaan dan untuk menyelesaikan masalah information asymmetry karena adanya perbedaan ownership dan control (Hidalgo, et al., 2011). Suatu bentuk jelas dari corporate governance adalah dengan adanya board of directors yang bertindak sebagai representasi shareholders untuk memonitor manajemen (Hennessey, 2015). Teori corporate governance telah lama dikenal dengan adanya board of directors yang bertindak atas nama shareholders untuk melakukan supervisi dan mengarahkan manajemen (Tarraf, 2011). Sehingga, dalam penelitian ini proksi corporate governance yang digunakan adalah dari segi board structure yaitu board size, board composition dan board meeting.

Corporate governance telah diakui sebagai mekanisme untuk mencapai suatu efisiensi yang maksimal dan berperan penting dalam menjaga sustainability, produktivitas dan profitabilitas perusahaan agar dapat memenuhi tantangan pada lingkungan global (Makki and Lodhi, 2014). Dalam lingkungan global, perusahaan juga harus memperhatikan faktor selain dari corporate governance untuk mendukung perusahaan mencapai kesuksesannya. Faktor tersebut adalah intellectual capital yang seringkala diabaikan oleh perusahaan. Zaman sekarang, perusahaan berkompetisi pada era "knowledge-based economy", semua pekerjaan teknikal digantikan dengan "knowledge workers" dan trend akan "learning organizations" berkembang pada era knowledge economy (Nazari and Herremans, 2007). Knowledge-based economy merupakan penggerak ekonomi yang menunjukkan bahwa value creation menjadi suatu hal yang penting. Komposisinya lebih dominan pada intangible assets dibandingkan tangible assets (Abdoli et al., 2013; Taliyang and Jusop, 2011). Dalam era knowledge-based economy, tentu knowledge-based asset merupakan hal yang penting untuk diinvestigasi karena knowledge-based era menyebabkan intellectual capital lebih penting daripada physical capital (Abdoli et al., 2013).

Untuk mengatasi, bertahan, bertumbuh dan memelihara kesuksesan bisnis, bergantung pada kemampuan perusahaan dalam menggunakan berbagai capital (baik financial, physical dan intellectual capital) yang dimiliki untuk menciptakan dan memelihara nilai sehingga perusahaan mencapai visi, misi dan tujuan keuangannya (Safieddine et al., 2009; Keenan and Aggestam, 2001). Makki and Lodhi (2014) berpendapat yang sama bahwa intellectual capital merupakan daya saing yang crusial untuk semua industri. Mekanisme internal corporate governance dapat bertahan di era knowledge-based economy melalui intellectual capital dan corporate knowledge merupakan salah satu sumber sustainable terpenting atas competitive advantages dalam berbisnis (Makki and Lodhi, 2014). Corporate governance sendiri merupakan bagian dan level tertentu dari intellectual capital yang berperan dalam control atas intellectual capital sebuah perusahaan (Keenan and Aggestam, 2001). Melalui corporate governance, board of directors memiliki tanggung jawab untuk meningkatkan intellectual capital dan mencapai efisiensi maksimun atas penggunaan sumberdaya intellectual capital yang dimiliki, sehingga akan meningkatkan kinerja keuangan perusahaan (Makki and Lodhi, 2014).

Knowledge-based economy juga membuat lingkungan bisnis semakin kompetitif. Lingkungan bisnis yang kompetitif menyebabkan manager lebih berhati-hati dalam menentukan aktivitas pendanaan bisnisnya dan untuk mengatur komposisi pendanaan secara tepat (Jahanzeb et al., 2014). Capital structure merupakan hal yang sangat penting untuk kesejahteraan keuangan perusahaan (Jaradat, 2015). Dalam penentuan keputusan pendanaan, corporate governance menjadi salah satu pertimbangan (Kajananthan, 2012; Vakilifard et al., 2011). Pemimpin harus melakukan yang terbaik dalam penentuan capital structure agar meningkatkan nilai perusahaan dan stakeholders-nya. 


\section{Teori Agency dan Teori Stewardship}

Agency theory merupakan perspektif teoritikal yang paling dominan dan yang banyak digunakan oleh para peneliti (L'Huillier, 2014). Agency theory telah menjadi paradigma yang dominan untuk memahami dan menjelaskan isu-isu mengenai corporate governance (Rubach and Sebora, 2009). Agency Theory didefinisikan sebagai sebuah kontrak, yaitu satu atau beberapa orang (the principal) menugaskan orang lainnya (the agent) untuk melakukan beberapa service, didalamnya termasuk mendelegasi beberapa otoritas decision making (Eisenhardt, 1989; Jensen and Meckling, 1976). Pendelegasian otoritas decision-making oleh principal kepada agent adalah karena harapan principal adalah bahwa agent akan bekerja sesuai dengan kepentingannya (Bonazzi and Islam, 2007). Yang menjadi principal adalah shareholders, sedangkan yang menjadi agent adalah manager/manajemen perusahaan (Altuner et al., 2015; Bonazzi and Islam, 2007). Agency conflict terjadi ketika agent tidak melakukan pekerjaan sesuai dengan kepentingan serta tujuan principal. Hal yang mendasar dari agency problem adalah karena adanya pemisahaan antara ownership dan control (Hennessey, 2015; Dawar, 2014; Cho and Wu, 2014; Krause and Semadeni, 2013; Shleifer and Vishny, 1997; Jensen and Meckling, 1976). Corporate governance dapat digunakan sebagai mekanisme pemonitoran untuk mengurangi konflik kepentingan antara para managers dan stakeholders (Hennessey, 2015; Dimitropoulos, 2014; Cho and $\mathrm{Wu}, 2014)$. Terdapat beberapa cara untuk mengurangi agency problem dalam hubungannya dengan corporate governance (Patel, et al., 2002) yaitu dengan adanya board of directors yang vigilant, dengan adanya pengungkapan atas informasi keuangan yang tepat waktu dan cukup, dan bahkan dengan adanya struktur kepemilikan yang transparan.

Sebuah corporate governance yang efektif dapat meminimalkan agency cost dan masalahmasalah mengenai pemisahaan kepemilikan dan control (Maher and Andersson, 1999). Perusahaan dengan tingkat corporate governance yang tinggi seharusnya dapat menghindari konflik kepentingan dibandingkan dengan perusahaan yang tingkat corporate governancenya masih rendah (Jaradat, 2015). Sehingga, para investor mengharapkan agar perusahaan dapat menerapkan corporate governance dengan tujuan agar investor mendapatkan tingkat pengembalian yang lebih baik atas investasi yang dilakukan dan juga untuk mengurangi adanya agency cost yang berlebihan (Aras and Crowther, 2008).
Stewardship theory lebih menekankan pada motif non-keuangan dalam melihat aktivitas managerial (Donaldson and Davis, 1991). Hal tersebut termasuk adanya kebutuhan akan pencapaian dan pengakuan, kepuasan intrinsik dalam mencapai suatu kinerja yang memuaskan dan etika kerja yang kuat (L'Huillier, 2014). Manager disebut sebagai good steward, yang merupakan suatu kesatuan dalam team players. Manager tidak dimotivasi oleh kepentingan individual, namun bersama-sama menyatukan diri dengan tujuan dan kepentingan principal-nya (Davis et al., 1997).

Stewardship theory bertentangan dengan agency theory. Manager dianggap memiliki opportunistic behavior yang akan memaksimalkan kepentingan pribadinya sendiri dan hal tersebut dapat bersifat merugikan bagi pihak lainnya (L'Huillier, 2014). Selain itu, seorang steward percaya bahwa adanya trade-off antara kebutuhan pribadi dengan tujuan organisasi. Sehingga, jika seorang steward bekerja sesuai dengan tujuan organisasi, maka keperluan pribadinya pun akan terpenuhi. Steward percaya bahwa manfaat yang didapatkan dari pro-organizational behavior akan lebih tinggi dibandingkan dengan maanfaat yang didapatkan dari self-serving berhavior. Sehingga, dalam stewardship theory, corporate governance berfokus pada struktur yang menfasilitasi dan memberdayakan para manager dibadingkan dengan melakukan monitor dan control (Davis et al., 1997).

\section{Corporate Governance}

Menurut Hennessey (2015) corporate governance adalah serangkaian aksi dan prosedur yang memastikan bahwa sebuah perusahaan dikelola dengan baik sehingga investors mendapatkan return yang sebanding dengan risiko atas investasi yang dilakukannya. Hal yang serupa juga dikatakan oleh Letza et al., (2008), corporate governance berhubungan dengan regulasi, supervisi, dan pengawasan terhadap kelalaian sebuah perusahaan. Sejalan dengan OECD, Safieddine et al., (2009) juga mengemukakan hal yang serupa yaitu corporate governance adalah serangkaian aturan yang mengatur tentang hubungan antara manajemen dengan karyawannya dan aktivitas-aktivitas yang diperlukan untuk menciptakan nilai.

Mekanisme corporate governance terdiri dari mekanisme eksternal dan internal (Altuner et al., 2015). Penelitian tersebut mengungkapkan bahwa mekanisme internal adalah mekanisme yang spesifik dan merupakan semua tindakan yang dilakukan oleh perusahaan untuk menerapkan control dan akuntanbilitas. Sedangkan meka- 
nisme eksternal berperan sebagai suplemen terhadap proses internal governance, menetapkan kerangka yang menyeluruh dan terintegrasi dengan mekanisme internal. Beberapa mekanisme internal corporate governance adalah board of directors, departemen internal audit dan komite audit, yang bertujuan untuk meningkatkan efektivitas manajemen perusahaan (Chalevas and Tzovas, 2010). Board of directors dikelompokan menjadi dua, yaitu board structure dan board ownership. Board structure dan ownership structure berpengaruh terhadap kinerja perusahaan (Adams, et al, 2010). Menurut Mili and Abid (2016), terdapat tiga variabel untuk mengukur board structure, yaitu board size, board meeting dan board independency.

Board Size; Board of directors merupakan salah satu komponen penting dari corporate governance sebagaimana shareholders telah mendelegasi autoritas kepada board untuk mengawasi dan mengontrol keputusan manajemen (Dorata and Petra, 2008). Board of directors memiliki fiduciary duty untuk melindungi kepentingan shareholders (Adams et al., 2010). Hal serupa juga dikatakan oleh Fama and Jensen (1983), bahwa kehadiran board of directors adalah untuk memonitor manajemen dan untuk melindungi kepentingan shareholders. Sehingga, pengembangan board yang efektif merupakan hal penting dan pilihan yang layak dilakukan untuk mencapai corporate governance yang optimal (Bonazzi and Islam, 2007). Board size mengarah pada jumlah anggota dewan direksi organisasi baik itu executive dan nonexecutive (Dibia dan Onwuchekwa, 2014). Terdapat beberapa penelitian yang menyatakan beberapa pendapat yang berbeda mengenai board size. Menurut Xie et al (2003) board yang kecil lebih kurang memiliki masalah birokrasi dan lebih fungsional. Ukuran board yang kecil juga lebih memberikan pengawasan terhadap pelaporan keuangan yang lebih baik. Sehingga dapat dikatakan ukuran board yang kecil lebih efektif dibandingkan ukuran board yang besar (Yermack, 1996; Eisenberg et al, 1998). Namun terdapat beberapa peneliti yang memiliki pendapat yang sebaliknya Lehn et al., (2004) menyatakan dengan ukuran board yang besar dan jumlah non- executive directors yang meningkat dapat memberikan keuntungan berupa pengumpulan informasi yang banyak dan terkumpulnya keahlian-keahlian yang beranekaragam yang dapat digunakan sebagai pendukung dalam aktiviats pengawasan (Rahman dan Ali, 2006). Sehingga menurut Alves (2011) ukuran board yang besar lebih efektif dibandingkan ukuran board yang kecil.

Board Composition; Board of directors umumnya dibagi menjadi dua kelompok, yaitu inside directors dan outside directors (Adams et al. 2010;
Hart, 1995). Inside directors adalah direksi yang bekerja secara full-time di perusahaan. Sedangkan outside directors adalah direksi yang tidak bekerja secara full-time di sebuah perusahaan, namun mereka dapat bekerja secara full-time di perusahaan yang lain (Adams et al., 2010). Terdapat istilah lainnya, yaitu inside directors adalah executive directors sedangkan outside directors adalah nonexecutive directors atau independent directors (Hart, 1995). Outside directors dipersepsikan lebih efektif merepresentasikan shareholders dalam melakukan monitor terhadap manajemen karena mereka adalah orang independen (Ameer et al. 2010). Di Indonesia, berdasarkan peraturan Otoritas Jasa Keuangan bernomor 33/POJK.04/2014 menyatakan sebuah perusahaan harus memiliki setidaknya komisaris independen sebanyak 30\% dari total anggota dewan komisaris.

Board Meeting; Karakteristik lain yang berhubungan dengan Board of directors adalah aktivitas, yang dapat diukur dengan jumlah meeting yang dilakukan di dalam suatu perusahaan (Gonza'lez dan Meca, 2014). Vafeas (1999) menyatakan board activity merupakan proxy yang baik untuk mengawasi aktivitas dari board of directors. Namun board meeting memiliki beberapa biaya seperti managerial time, travel expenses, dan directors' meeting fees. Selain itu juga terdapat keuntungan seperti banyaknya waktu bagi board of director untuk berunding, mengatur strategi, dan mengawasi management. Directors yang memiliki banyak waktu untuk berunding maka akan membuat keputusan yang lebih baik. Dengan adanya aktivitas monitoring yang lebih baik yang diproksikan dengan peningkatan board activity diharapkan akan meningkatkan kinerja perusahaan. Selain itu, Chen et al (2006) menyarankan bahwa tingginya jumlah pertemuan direksi akan mengurangi kemungkinan fraud. Karena dengan adanya regular meetings, para board of directors dapat mengidentifikasi dan menyelesaikan masalah-masalah yang berpotensi terjadi. Selain itu, board of directors yang secara aktif sering melakukan pertemuan, lebih mungkin untuk melakukan tugas mereka sesuai dengan kepentingan shareholders (Siam, et al., 2014).

\section{Intellectual Capital}

Keenan and Aggestam (2001) mengatakan bahwa intellectual capital adalah konversi atas pengetahuan menjadi sesuatu yang menghasilkan nilai. Sehingga intellectual capital dapat didefinisikan sebagai penjumlahan dari knowledge dan kapabilitas yang digunakan perusahaan untuk mencapai competitive advantages (Youndt et al. 2004). Ståhle et al. (2011) memberikan pengertian intellectual capital yang lebih komprehensif, yaitu 
intellectual capital adalah sumber penciptaan added kepada perusahaan, dimana sumberdaya tersebut berupa sumberdaya tidak berwujud dan non physical yaitu human capital (ketrampilan, pengalaman, training $\mathrm{dsb}$ ), relational capital (hubungan dengan customer dan stakeholders, brands, agreements) dan structural capital (budaya perusahaan, lingkungan kerja, sistem).

Intellectual capital dapat meningkatkan kinerja dan menciptakan nilai (value) kepada perusahaan (Appuhami and Bhuyan, 2015). Value creation ini akan mendorong perusahaan untuk melakukan investasi yang cukup besar, sehingga dapat menambah nilai intellectual capital sebuah perusahaan. Maaloul and Zéghal (2015) mengatakan bahwa perusahaan akan melakukan investasi seperti pada research and development (RD), human resources, employee training, customer relations dan information systems, karena investasi pada intellectual capital tersebut menjadi value creators yang sangat tepat pada zaman sekarang. Namun investasi atas intellectual capital masih belum diakui secara jelas dalam pengakuan akuntansi di dalam laporan keuangan. Maaloul dan Zéghal (2015) mengutip dari Financial Accounting Standards Board (FASB), alasan yang menghalangi pengakuan intellectual capital di dalam laporan keuangan adalah karena sulitnya untuk mengontrol, mengukur serta mengevaluasi future cash flow. Sehingga, hal yang menyebabkan adanya perbedaan antara book value dan market value perusahaan adalah karena intangible assets (intellectual capital) yang dihilangkan dari laporan keuangan (Abdoli et al., 2013).

Ketidakmampuan laporan keuangan untuk mewadahi pengakuan intellectual capital, dapat diimbangi dengan pengungkapan manajemen atas aktivitas perusahaan terkait pengembangan intellectual capital perusahaan. Hal ini kenal dengan intellectual capital disclosure (ICD). Telah banyak perusahaan yang berusaha memenuhi permintaan stakeholders dengan cara melengkapi laporan keuangan dengan laporan non-keuangan, termasuk informasi IC (Abeysekera, 2008). ICD ini adalah voluntary reporting, yang ketika dihubungkan dengan agency theory, menyiratkan bahwa pengungkapan IC secara sukarela dapat mengurangi masalah information asymmetry dalam konflik agency-principal, sehingga dapat meningkatkan nilai perusahaan (An, et al., 2011). Guthrie et al. (2004) mengelompokkan ICD ke dalam tiga kelompok besar, yaitu internal capital (termasuk di dalamnya sistem manajemen perusahaan, kebijakan, budaya, dan berbagai organizational capabilities); external capital (meliputi hubungan dengan pihak-pihak di luar perusaha- an); dan human capital (meliputi know-how, capabilities, skills, dan expertise yang dimiliki karyawan). Ketiga katogori ini yang paling sering digunakan dalam penelitian tentang ICD, seperti yang dilakukan oleh Haji dan Ghazali (2013), dan Keenan and Aggestam (2001) ketika menguji pengaruh corporate governance terhadap ICD.

Metode pengukuran intellectual capital yang akan digunakan dalam penelitian ini adalah Value Addedd Intellectual Capital (VAIC), yang pertama kali dikemukakan oleh Pulic pada tahun 1998 dan dikembangkan lagi oleh Borhemann pada tahun 1999 (Appuhami and Bhuyan, 2015; Chang and Hsieh, 2011; Murale et al., 2010). Pulic berpendapat bahwa indikator yang tepat untuk mengukur kinerja pada era knowledge-based economy adalah value added (Iazzolino and Laise, 2013). Pengukuran yang dikembangkan oleh Pulic ini berangkat dari pendekatan investment-based yang menggunakan informasi yang disajikan dalam income statement dengan pertimbangan bahwa semua beban yang terkait IC adalah sebuah investasi, bukan sebagai beban. Pulic (1998) mengusulkan VAIC sebagai indikator dari IC, mensejajarkan human expenses sebagai human capital yang akan menghasilkan nilai tambah. Pulic mengembangkan rumusan VAIC dari komponen utama dalam sumber daya perusahaan, yaitu human capital efficiency (HCE), structural capital efficiency (SCE), capital employed efficiency (CEE). Beberapa langkah yang diperlukan dalam menghitung $V A I C$ adalah:

a. Value Added (VA) $=\mathrm{OP}+\mathrm{HC}+\mathrm{D}+\mathrm{A}$ Dimana: $\mathrm{OP}=$ operating; $\mathrm{HC}=$ human cost $; \mathrm{D}=$ depreciation; $\mathrm{A}=$ amortization

b. Human Capital Efficiency $(\mathrm{HCE})=\mathrm{VA} / \mathrm{HC}$ Dimana: $\mathrm{VA}=$ value added $; \mathrm{HC}=$ human cost

c. Structural Capital Efficiency (SCE) = SC/VA Dimana: $\mathrm{SC}=$ structural capital

$(\mathrm{SC}=\mathrm{VA}-\mathrm{HC}) ; \mathrm{VA}=$ value added

d. Capital Employed Efficiency (CEE) = VA / CE Dimana: $\mathrm{VA}=$ value added; $\mathrm{CE}=$ capital employed

e. $\mathrm{VAIC}=\mathrm{HCE}+\mathrm{SCE}+\mathrm{CEE}$

VAIC dianggap sangat penting karena dapat mengukur semua kontribusi dari setiap sumberdaya (human, structural, physical dan financial) untuk menciptakan value added kepada perusahaan (Iazzolino and Laise, 2013; Zéghal and Maaloul, 2010). Sehingga, alasan utama digunakannya VAIC sebagai indikator atas intellectual capital karena $V A I C$ menggunakan data dari laporan keuangan dan hal tersebut akan mengurangi adanya kemungkinan subjektifitas atas data yang diperoleh (Chang and Hsieh, 2011). 


\section{Corporate Governance dan Intellectual Capital}

Hubungan antara corporate governance dengan intellectual capital berawal dari adanya fakta bahwa managerial decision-making berfokus pada penciptaan nilai kepada stakeholders melalui penggunaan capital yang dimiliki. Corporate governance menggunakan financial capital, physical plant, dan intellectual capital untuk menciptakan dan memelihara penciptaan nilai tersebut. Sehingga, corporate governance dengan intellectual capital memiliki hubungan, dimana atribut dari corporate governance seperti independent directors dapat meningkatkan kualitas pemonitoran perusahaan terhadap keputusan penting mengenai investasi pada intellectual capital dan kinerja perusahaan (Keenan and Aggestam, 2001).

Jumlah board of directors telah diidentifikasikan sebagai sebuah faktor yang mempengaruhi tingkat pengungkapan atas intellectual capital perusahaan karena pada umumnya pengungkapan atas informasi merupakan strategic decision yang biasanya ditetapkan oleh para board (Oba, et al., 2013). Resource dependence theory mengatakan bahwa dengan adanya jumlah board yang semakin banyak (larger board) menunjukan adanya pool of expertise yang tinggi pula (Pfeffer, 1972; Hidalgo et al., 2011). Hal tersebut juga akan memberikan banyaknya perspektif dalam pengambilan keputusan (Lipton and Lorsh, 1992). Selain itu, Haji and Ghazali (2013) menambahkan bahwa dengan large board maka akan meningkatkan efektivitas pemonitoran dalam menangani aktivitas organisasi. Hubungan antara board size dengan intellectual capital telah diteliti sebelumnya. Haji and Ghazali (2013); OBA et al., 2013; Lucyanda and Rahmayanti, 2012; Hidalgo et al., 2011; menemukan adanya hubungan positif antara board size dengan level pengungkapan intellectual capital. Sehingga, hipotesis dalam penelitian ini adalah:

H1: Board size berpengaruh positif terhadap VAIC.

Tujuan adanya independent director adalah untuk meningkatkan efektivitas pemonitoran dan pengendalian terhadap manajemen, dimana hal ini dilakukan untuk mengurangi agency problem (Appuhami dan Bhuyan, 2015). Sehingga, dengan adanya orang independent dalam boards maka akan memberikan pemonitoran dan control atas perusahaan yang lebih efektif. Hal tersebut berarti dengan adanya boards yang sebagian besar adalah independent directors akan lebih cenderung meminimalkan eksploitasi yang dilakukan oleh top management atas kekayakaan shareholders dan menggunakan intellectual capital secara efisien untuk memberikan nilai tambah kepada perusahaannya (Appuhami dan Bhuyan, 2015).
Terdapat beberapa penelitian terdahulu yang menemukan hubungan yang positif antara independent directors dengan intellectual capital (Ho and Williams, 2003; Haji and Ghazali, 2013; Appuhami dan Bhuyan, 2015). Sehingga, hipotesis dalam penelitian ini adalah:

H2: Board composition berpengaruh positif terhadap VAIC.

Komitmen dari para board of directors bisa dilihat dari frekuensi meeting yang dilakukan board of directors. Board meeting yang efektif merupakan sebuah peran yang sangat penting dalam mengurangi kelemahan board diversity dan akan meningkatkan kinerja intellectual capital (AlMusali and Ismail, 2015). Board meeting juga akan meningkatkan kapasitas pemonitoran dan penyelesaian masalah yang lebih cepat atas permasalahan yang dihadapi perusahaan (Brick and Chidambaram, 2010; Vafeas, 1999).

Semakin meningkatnya complexity lingkungan bisnis, maka dukungan dari board kepada para manager dan karyawan semakin diperlukan. Kualitas dari frekuensi board meeting dapat terlihat dari kebijakan yang dibuat dalam mendukung manajemen untuk meningkatkan nilai tambah (Finkelsteiun et al., 2009). Sehingga, hipotesis dalam penelitian ini adalah:

H3: Board meeting berpengaruh positif terhadap VAIC.

\section{Firm Size dan Intellectual Capital}

Semakin besar perusahaan maka akan semakin meningkatkan investasi yang lebih mengenai intellectual capital, hal ini dikarenakan peningkatan pada financial solvency (Appuhami dan Bhuyan, 2015). Pernyataan di atas juga di dukung oleh Hidalgo et al. (2011) yang menyatakan semakin besar perusahaan maka akan lebih mengungkapkan informasi yang lebih mengenai intellectual capital. Selain itu terdapat penelitian terdahulu lainnya yang menemukan adanya pengaruh firm size terhadap intellectual capital seperti Gonza lez dan Meca (2014) yang menyatakan terdapat pengaruh positif firm size terhadap IC. Sehingga, hipotesis dalam penelitian ini adalah:

H4: Firm size berpengaruh positif terhadap VAIC.

\section{Leverage dan Intellectual Capital}

Dalam free cash flow theory, setelah mendanai semua project yang menghasilkan positive cash flow, maka sisa cash flow tersebut bisa digunakan oleh manager untuk memenuhi kepentingan dan keuntungan pribadinya (Tahir and Fraz, 2015). Jensen (1986) berargumen bahwa debt dapat menjadi sebuah mekanisme disciplinary 
yang menghalangi managers dalam menggunakan menggunakan free cash flow untuk hal yang tidak tepat. Hal tersebut mengakibatkan debt memiliki hubungan yang negatif terhadap employee benefit (Jensen, 1986). Hal serupa juga dikatakan oleh Hanka (1998), dimana penggunaan debt yang banyak berhubungan dengan employment reductions, lower wages dan penurunan pendanaan pension karyawan. Sebagaimana diketahui bahwa human capital merupakan bagian dari intellectual capital, sehingga dengan adanya penurunan human capital maka akan berpengaruh terhadap intellectual capital secara keseluruhan. Pengaruh leverage dengan intellectual capital telah diteliti sebelumnya. Belkaoui and Karpik (1989); Lucyanda and Rahmayanti (2012); Aslam et al., (2014) menemukan leverage berpengaruh negatif terhadap intellectual capital. Sehingga, hipotesis dalam penelitian ini adalah:

H5: Leverage berpengaruh negatif terhadap VAIC.

\section{METODE PENELITIAN}

\section{Sumber Data dan Pemilihan Sample}

Sebagaimana telah dijelaskan di atas, penelitian ini menguji pengaruh board size, board composition, board meeting, firm size, dan leverage terhadap Value Added Intellectual Capital. Model penelitian ini adalah:

$\mathrm{VAIC}=80+81 \mathrm{BS}+82 \mathrm{BC}+83 \mathrm{BM}+84 \mathrm{FS}-65$ $\mathrm{LEV}+\varepsilon$

\section{Definisi Operasional dan Pengukuran Varia- bel}

Berikut ini operasional yang digunakan untuk masing-masing variabel dijabarkan dalam Tabel 1.

Penelitian ini merupakan penelitian kuantitatif, menggunakan data sekunder yang diperoleh dari laporan keuangan tahunan publikasi Bursa Efek Indonesia. Populasi yang digunakan adalah perusahaan yang berada di industri perdagangan, jasa dan investasi (sub sektor perdagangan besar dan perdanagan eceran) dan industry barang konsumsi (sub-sektor rokok, farmasi, kosmetik dan keperluan rumah tangga, peralatn rumah tangga, beserta makanan dan minuman). Teknik sampling yang digunakan adalah purposive sampling dengan kriteria: 1) Dalam sub-sektor yang sesuai dengan populasi yang telah ditentukan, dan aktif dalam tahun 2010 hingga 2015; 2). Data laporan keuangan tersedia lengkap dalam periode 20102015 ; 3) tahun buku ditutup pada 31 Desember; 4) menggunakan mata uang rupiah. Setelah melewati tahapan test normalitas, total pengamatan adalah 112 tahun laporan keuangan.
Tabel 1. Measurement of Variables

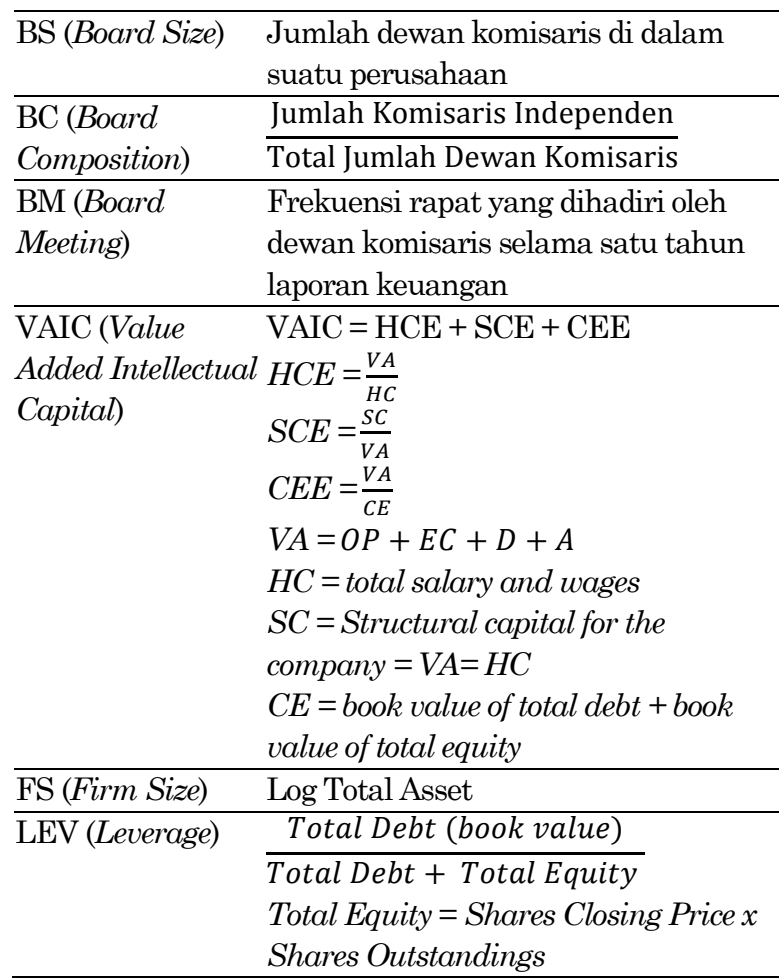

Model penelitian diuji menggunakan metode ordinary least square (OLS), khususnya multiple regression, untuk menguji apakah Board Structures (dalam penelitian ini diwakili oleh BS, BC, dan BM) memiliki pengaruh terhadap VAIC. Sebelum test hipotesis dilakukan, model harus fit dan memenuhi asumsi klasik, yaitu asumsi terdistribusi secara normal, tidak adanya heteroskedastisitas, tidak ada multikolinearitas, dan tidak adanya autokorelasi.

\section{HASIL PENELITIAN DAN PEMBAHASAN}

\section{Deskripsi Obyek Penelitian}

Setelah melalui kriteria sampling dan uji model regresi, maka diperoleh gambaran objek penelitian yang dirangkum dalam Tabel 2 berikut ini.

Tabel 2 menunjukkan rata-rata board size tertinggi yaitu sekitar 5 orang dimiliki oleh sub sektor perdagangan eceran, hal ini mengindikasikan bahwa rata-rata perusahaan-perusahaan yang terdaftar di sub sektor tersebut memiliki jumlah dewan komisaris yang paling banyak jika dibandingkan dengan perusahaan di sub sektor yang lain. Jumlah board size terkecil yaitu sekitar 2 orang saja dimiliki oleh perusahaan yang digolongkan ke dalam sub sektor perlatan rumah tangga. 
Tabel 2. Deksripsi Statistik

\begin{tabular}{|c|c|c|c|c|c|c|}
\hline Sub Sektor & $\begin{array}{l}\text { Mean } \\
\text { Bsize }\end{array}$ & $\begin{array}{l}\text { Mean } \\
\text { Bind }\end{array}$ & $\begin{array}{l}\text { Mean } \\
\text { Bmeet }\end{array}$ & $\begin{array}{l}\text { Mean } \\
\text { Fsize }\end{array}$ & $\begin{array}{c}\text { Mean } \\
\text { Laverage }\end{array}$ & $\begin{array}{l}\text { Mean } \\
\text { VAIC }\end{array}$ \\
\hline $\begin{array}{l}\text { Makanan dan } \\
\text { minuman }\end{array}$ & 3.5000 & 0.3938 & 7.9375 & 11.9930 & 0.2563 & 3.1128 \\
\hline Rokok & 4.0000 & 0.5000 & 4.0000 & 12.6904 & 0.2260 & 2.5423 \\
\hline Farmasi & 4.4167 & 0.3944 & 5.6667 & 12.0974 & 0.1303 & 2.8522 \\
\hline $\begin{array}{l}\text { Kosmetik \& } \\
\text { keperluan } \\
\text { rumah tangga }\end{array}$ & 3.0000 & 0.3333 & 4.3333 & 11.6359 & 0.0905 & 2.6424 \\
\hline $\begin{array}{l}\text { Peralatan } \\
\text { rumah tangga }\end{array}$ & 2.1429 & 0.4762 & 5.7143 & 11.7474 & 0.4730 & 2.1816 \\
\hline $\begin{array}{l}\text { Perdagangan } \\
\text { besar }\end{array}$ & 3.8542 & 0.3868 & 6.3750 & 12.1676 & 0.3289 & 2.9549 \\
\hline $\begin{array}{l}\text { Perdagangan } \\
\text { eceran }\end{array}$ & 4.8571 & 0.4333 & 5.3810 & 12.4754 & 0.1848 & 2.9739 \\
\hline Total & & & $112 \mathrm{ol}$ & bservasi & & \\
\hline Mean & 3.9107 & 0.4012 & 6.1429 & 12.1647 & 0.2659 & 2.8966 \\
\hline $\begin{array}{l}\text { Standard } \\
\text { Deviasi }\end{array}$ & 1.2983 & 0.0709 & 3.0369 & 0.6531 & 0.2201 & 0.5404 \\
\hline
\end{tabular}

Rata-rata komposisi independent director tertinggi di dalam dewan komisaris dimiliki oleh perusahaan-perusahaan yang terdaftar di sub sektor rokok (sebesar 50\%). Hal ini mengindikasikan bahwa independent director yang dimiliki sudah sesuai dengan ketentuan peraturan di Indonesia yang mengharuskan komposisi independent sebanyak 30\% dari total keseluruhan dewan komisaris. Presentasi terendah dimiliki oleh subsektor kosmetik \& keperluan rumah tangga yaitu sebesar $33 \%$.

Rata-rata BMEET terbanyak adalah pada subsektor makanan dan minuman yaitu sebanyak 7.93. Hal ini menunjukan bahwa rata-rata perusahaan pada subktor makanan dan minuman selama tahun 2010-2015 telah melakukan rapat kurang lebih hampir sebanyak 8 kali dalam setahun. Hal ini sudah sesuai dengan peraturan OJK yang mengharuskan perusahaan untuk melakukan rapat board setidaknya 4 kali dalam satu tahun. Untuk rata-rata BMEET terkecil yaitu ditempati oleh subsektor rokok dengan nilai sebesar 4.

Perusahaan yang terdaftar di sub sektor rokok rata-rata memiliki ukuran perusahaan yang besar dibandingkan dengan perusahaan di sub sektor lain, hal ini terlihat dari hasil rata-rata yang dimiliki di sub sektor tersebut adalah sebesar 12,69, angka tersebut mencerminkan total asset yang di miliki di dalam sub sektor rokok. Ukuran perusaan terkecil yang ditunjukkan dengan angka $\log$ total asset sebesar 11,64 dimiliki oleh perusahaan yang termasuk di dalam sub sektor kosmetik dan keperluan rumah tangga.

Nilai leverage tertinggi dimiliki oleh subsektor peralatan rumah tangga yaitu sebesar 0.47. Hal ini menunjukan bahwa proporsi penggunaan hutang dalam subsektor peralatan rumah tangga cukup tinggi. Subsektor ini hampir sebagian besar (mendekati 50\%) mengandalkan hutang dalam komposisi pendanaan bagi aktivitas operasional perusahaan. Sebaliknya, untuk nilai leverage terendah dimiliki oleh subsektor kosmetik dan keperluan rumah tangga yaitu hanya sebesar 0.09. Hal ini menandakan bahwa subsektor kosmetik dan keperluan rumah tangga lebih bersifat konservatif dalam penentuan komposisi pendanaan, karena memiliki ketakutan jika berhutang lebih banyak maka risiko default payment pun akan semakin tinggi.

Nilai VAIC tertinggi dimiliki oleh subsektor makanan dan minuman yaitu sebesar 3.11. Hal ini menunjukan bahwa selama tahun pengamatan, subsektor makanan dan minuman lah yang dapat memaksimalkan efisiensi penggunaan intellectual capital dan capital employed yang dimiliki perusahaan dengan lebih baik, sehingga menghasilkan nilai VAIC yang paling tinggi. Untuk nilai VAIC yang terendah dimiliki oleh subsektor peralatan rumah tangga yaitu sebesar 2.18. Perbedaan antara yang tertinggi dan terendah pun hampir mencapai setengah kalinya atau sebesar $42.66 \%$. Hal ini menunjukan bahwa subsektor peralatan rumah tangga kurang mampu memaksimalkan penggunaan intellectual capital dan capital employed-nya dengan lebih maksimal dibandingankan dengan subsektor lainnya dalam sample penelitian.

Tabel 3. Uji Normalitas dan Heterokedastisitas Dengan Variable Dependen VAIC

\begin{tabular}{ccccccccc}
\hline \multicolumn{1}{c}{ Spearman Roh Board Board Board Board Firm } \\
Correlation \\
\end{tabular}

Dalam Tabel 3 dapat dilihat asymp. sig. 2tailed One-Sample Kolmogorov-Smirnov Test mencapai angka 0,200. Dengan begitu, dapat dikatakan bahwa data yang akan digunakan untuk regresi VAIC berdistribusi normal (0,200 > 0,05). Dapat dilihat dari hasil di atas variabel board size $(0,931)$, board composition $(0,435)$, board meeting $(0,105)$, firm size $(0,512)$ dan leverage $(0,805)$. Hasil-hasil tersebut menunjukkan semua variabel terbebas dari heterokedastisitas, karena memiliki signifikan lebih dari 0,05 . 
Tabel 4. Uji Multikolinearitas dan Autokorelasi dengan Variabel Dependen VAIC

\begin{tabular}{|c|c|c|c|c|c|c|}
\hline & \multicolumn{2}{|c|}{$\begin{array}{l}\text { Collinearity } \\
\text { Statistics }\end{array}$} & \multicolumn{2}{|c|}{ Durbin Watson } & \multicolumn{2}{|c|}{ Fit Model Test } \\
\hline & Tolerance & VIP & DW stat & Du \& dl & F-test & $\begin{array}{c}\text { Adjusted } \\
\text { R2 }\end{array}$ \\
\hline Industry & 877 & 1,141 & & & & \\
\hline $\begin{array}{l}\text { Board } \\
\text { Size }\end{array}$ & 616, & 1,623 & & & & \\
\hline $\begin{array}{l}\text { Board } \\
\text { Comp }\end{array}$ & 826 & 1,210 & $\begin{array}{l}\mathrm{DW}= \\
1,910\end{array}$ & $\begin{array}{c}\mathrm{Du}= \\
1.670\end{array}$ & $\begin{array}{c}\mathrm{F}= \\
9.7158\end{array}$ & \\
\hline $\begin{array}{l}\text { Voard } \\
\text { Meeting }\end{array}$ & ,937 & 1,068 & $\begin{array}{c}\mathrm{du}<\mathrm{DW} \\
<4-\mathrm{du}\end{array}$ & $4-\mathrm{du}=$ & Sig. $=$ & 0,32 \\
\hline $\begin{array}{l}\text { Firm } \\
\text { Size }\end{array}$ & ,498 & 2,010 & & & & \\
\hline Lev & ,817 & 1,224 & & & & \\
\hline
\end{tabular}

Tabel 4 menunjukkan semua variabel independen memiliki nilai VIF yang lebih kecil dari 10 dan nilai tolerance lebih besar dari 0,10 . Hal ini mengindikasikan tidak adanya multikolinearitas antar variabel independen dalam model regresi ini. Tabel 4 juga menunjukkan hasil durbin watson (dw) yang menginterpretasikan hasil uji autokorelasi, dapat dilihat hasil du, dw, dan (4-du) masingmasing adalah 1,67, 1,91, dan 2,33. Jika dimasukkan dalam kriteria di atas, dapat disimpulkan bahwa model regresi VAIC terhindar dari autokorelasi $(1,67<1,91<2,33)$.

\section{Hasil Uji Hipotesis}

Tabel 4 menunjukkan bahwa model penelitian ini telah fit (sig F-test $>$ a 5\%), dengan adjusted $R$-square sebesar $32 \%$. Hal ini menunjukkan bahwa variabel Ind, BS, BC, BM, FS, dan Lev secara simultan mampu menjelaskan VAIC sebesar $32 \%$. Sisanya sebesar $68 \%$ adalah faktorfaktor lain di luar penelitian ini yang dapat mempengaruhi VAIC.

Tabel 5. Hasil Uji T Dengan Variabel Dependen VAIC

\begin{tabular}{lcccc}
\hline & $\begin{array}{c}\text { Un standardized } \\
\text { Coefficients }\end{array}$ & t-test & p-value Uji Hipotesa \\
\hline (Constant) & -.137 & -.142 & .887 & \\
Ind & -.018 & -.804 & .423 & \\
Board Size & .061 & 1.471 & .144 & H1 ditolak \\
Board Composition & -.331 & -.504 & .615 & H2 ditolak \\
Boaed Meeting & .037 & 2.557 & .012 & H3 diterima \\
Firm Size & .246 & 2.682 & .008 & H4 diterima \\
Leverage & -.771 & -3.627 & .000 & H5 diterima \\
\hline
\end{tabular}

Tabel 5 menunjukkan bahwa variabel Board Meeting, Firm Size, dan Leverage memiliki pengaruh signifikan pada $\alpha=5 \%((p-v a l u e<\alpha)$. Board Meeting memiliki pengaruh positip terhadap VAIC $(0,037)$; demikian juga dengan Firm Size (0.246). Leverage berpengaruh negatif terhadap VAIC (-0.771). Perbedaan subsektor industri (Variable
Ind) tidak signifikan, sehingga menunjukkan bahwa hasil penelitian ini berlaku sama untuk semua subsektor, tidak ada perbedaan hasil pengaruh untuk masing-masing subsektor yang menjadi objek penelitian ini.

\section{Pembahasan dan Implikasi Manajerial}

Hasil penelitian yang diperoleh adalah board size tidak memiliki pengaruh terhadap VAIC. Hal ini sesuai dengan penelitian Al-Musali and Ismail (2012); Ho and Williams (2003). Salah satu analisa ditolaknya $\mathrm{H} 1$ dapat disebabkan oleh jumlah board yang tidak dispesifikasikan dalam Pedoman Umum CGC yang diterbitkan oleh KNKG. Sehingga, dengan jumlah board berapapun tidak akan berpengaruh terhadap strategi managerial (termasuk manajemen intellectual capital) yang ditetapkan perusahaan dalam upaya mengoptimalisasi kinerja perusahaan. Hasil penelitian ini bertentangan dengan agency theory karena menurut agency theory ukuran board dalam perusahaan akan mempengaruhi efektivitas pengontrolan dan pemonitoran terhadap perilaku dan aktivitas manajemen. Control dan monitor ini termasuk di dalamnya mengawasi aktivitas investasi perusahaan terhadap intellectual capital dan bagaimana perusahaan dapat menggunakan intellectual capital yang dimiliki dengan seefisien mungkin untuk memberikan value added kepada perusahaan.

Board composition tidak memiliki pengaruh terhadap VAIC. Hal ini sejalan dengan penelitian Arifin et al. (2014); Abdoli et al. (2013); Oba et al. (2013); Taliyang and Jusop (2011); Hidalgo et al. (2011). Hal ini bisa disebabkan karena board of director yang indepeden (outside directors) pada umumnya memiliki waktu yang lebih singkat diperusahaan dan tidak begitu menerima informasi yang lebih dalam mengenai perusahaan seperti informasi yang diterima inside directors (Hidalgo et al., 2011). Hasil penelitian ini bertentangan dengan agency theory karena menurut agency theory tujuan adanya komposisi independent director adalah untuk meningakatkan efektivitas monitoring dan control yang lebih tinggi terhadap management dan mengurangi masalah agency yang mungkin timbul dalam aktivitas operasional perusahaan. Sebagaimana diketahui bahwa independent directors lebih merepresentasikan kepentingan shareholders. Sehingga, independent directors akan berusaha untuk meningkatkan kinerja perusahaan. Dengan meningkatkan kinerja perusahaan (termasuk kinerja intellectual capital) maka akan memenuhi tujuan perusahaan yaitu untuk meningkatkan shareholders'wealth. 
Board meeting memiliki pengaruh positif terhadap VAIC. Board meeting yang semakin banyak mengindikasikan bahwa board members yang aktif dapat menangani mengenai isu strategis perusahaan. Kemampuan ini yang menggambarkan kemampuan intellectual perusahaan (Al-Musali and Ismail, 2015). Brick and Chidambaram (2010), dan Saeed et al. (2015) menunjukkan bahwa semakin banyak frekuensi board meetings, maka menyiratkan semakin sering manajemen melakukan evaluasi terhadap kegiatan operasional perusahaan, sehingga dapat meningkatkan kinerja perusahaan, termasuk meningkatnya VAIC perusahaan.

Hasil yang diperoleh mengenai variabel kontrol firm size dan leverage adalah terdapat pengaruh yang positif antara firm size dengan VAIC. Hasil penelitian ini sesuai dengan penelitian Hidalgo et al. (2011); Guthrie, et al. (2006); Li et al (2012); Oba et al. (2013); Lucyanda dan Rahmayanti (2012). Pemgaruh positip ini menunjukkan bahwa semakin besar perusahaan maka akan semakin meningkatkan investasi yang lebih mengenai intellectual capital, hal ini dikarenakan peningkatan pada finanial solvency (Appuhami dan Bhuyan, 2015). Selain itu semakin besar perusahaan maka akan mengungkapkan informasi yang lebih mengenai intellectual capital (Hidalgo et al, 2011).

Selanjutnya, Leverage memiliki hubungan negative terhadap intellectual capital. Hasil ini sesuai dengan penelitian Lucyanda and Rahmayanti (2012); Aslam et al. (2014); Belkaoui and Karpik (1989). Capital structure adalah suatu hal yang relevan dan memiliki pengaruh terhadap VAIC di perusahaan, walaupun hubungan antara keduanya saling berlawanan. Hal ini berarti bahwa semakin tingginya debt maka akan menurunkan efisiensi intellectual capital perusahaan. Selain itu, dalam agency theory, Jensen (1986) berargumen bahwa debt dapat menjadi sebuah mekanisme disciplinary yang menghalangi managers dalam menggunakan menggunakan free cash flow untuk hal yang tidak tepat. Hal tersebut mengakibatkan debt memiliki hubungan yang negatif terhadap employee benefit yang merupakan bagian dari intellectual capital performance.

\section{KESIMPULAN DAN SARAN}

Penelitian ini adalah penelitian asosiatif yang bertujuan untuk menguji pengaruh board structures sebagai indikator dari corporate governance terhadap Value-Added Intellectual Capital dengan mempertimbangkan firm size dan leverage sebagai variabel kontrol. Perbedaan subsektor juga dipertimbangkan, namun hasilnya menunjukkan bahwa tidak ada beda pengaruh diantara masingmasing subsektor tersebut. Variabel independen BS (H1) dan BC (H2) tidak memiliki pengaruh terhadap VAIC, dimana hal ini bertentangan dengan agency theory. Variabel independen BM (H3) memiliki pengaruh positif terhadap VAIC. Variabel kontrol yaitu FS (H4) memiliki pengaruh positif terhadap VAIC) dan Leverage (H5) memiliki pengaruh negatf terhadap VAIC. Para dewan komisaris diharapkan dapat meningkatkan kinerjanya melalui board meeting yang efektif, agar dewan komisaris dapat menangani masalahmasalah strategis yang berkaitan dengan intellectual capital.

Koefisien determinasi $\mathrm{R}^{2}$ yang diperoleh adalah sebesar $32 \%$ untuk pengujian pengaruh variabel independen terhadap variabel dependen VAIC. Hal ini menunjukkan bahwa variabel bebas hanya dapat menjelaskan sebanyak $32 \%$ variasi variabel terikat, sisanya dijelaskan oleh variabel atau faktor lain diluar model regresi.

Penelitian ini hanya menguji pada industri manufaktur barang konsumsi dan industri perdagangan yang terdaftar di Bursa Efek Indonesia, namun 2 industri ini tidak bisa dikatakan dapat mencerminkan pengaruh corporate governance terhadap intellectual capital di Indonesia secara general karena di Indonesia terdiri dari banyak industri yang memiliki karakteristik yang berbeda-beda. Penelitian selanjutnya dapat menguji model ini pada sektor industri yang berbeda atau menggabungkan semua sektor industri yang ada.

Penelitian ini menggunakan VAIC sebagai proxy intellectual capital, untuk penelitian selanjutnya dapat menggunakan pengukuran intellectual capital lainnya dan mempertimbangkan untuk menggunakan nilai pasar untuk menilai intellectual capital.

\section{DAFTAR PUSTAKA}

Abdoli, M., Panahi, H., and Rahimiyan, F. (2013). The effect of corporate governance factors on the improvement of intellectual capital. Journal of Social Issues \& Humanities, 1(7), 74-80.

Abeysekera, I. (2008). Intellectual capital disclosure trends: Singapore and Sri Lanka. Journal of Intellectual Capital, 9(4), 723-737.

Adams, R., Hermalin, B. and Weisbach, M. (2010). The role of boards of directors in corporate governance: a conceptual framework and survey. Journal of Economic Literature, 48(1), 58107.

Al-Musali, M. A. K. and Ismail, K. N. I. K. (2015). Board diversity and intellectual capital performance. The moderating role of the effectiveness of board. Accounting Research Journal, 28(3), 268-283. 
Altuner, D., Çelik, S. and Guile, T., C. (2015). The linkages among intellectual capital, corporate governance and corporate social responsibility. Corporate Governance: The International Journal of Business in Society, 15(4), 491-507.

Alves, S. M. G. (2011). The effect of the board structure on earnings management:

Evidence from Portugal. Journal of Financial Reporting \& Accounting, 9(2), 141-160.

Ameer, R., Ramli, F. and Zakaria, H. (2010). A new perspective on board composition and firm performance in an emerging market. Corporate Governance: The international journal of business in society, 10(5), 647-661.

An, Y., Davey, H. and Eggleton, I.R.C. (2011). Towards a comprehensive theoretical framework for voluntary IC disclosure. Journal of Intellectual Capital, 12(4), 571-585.

Appuhami, A. and Bhuyan, M. (2015). Examining the influence of corporate governance on intellectual capital efficiency. Managerial Auditing Journal, 30(4/5), 347-372.

Aras, G. and Crowther, D. (2008). Governance and sustainability: an investigation into the relationship between corporate governance and corporate sustainability. Management Decision, 46(3), 433-448.

Arifin, J., Suhadak, Astuti, E. S. and Arifin, Z. (2014). The influence of corporate governance, intellectual capital on financial performance and firm value of bank sub-sector companies listed at Indonesia stock exchange in period 2008-2012. European Journal of Business and Management, 6(26), 159-167.

Aslam, S, Makki, M. A. M., Nawaz, H. M. and Latif, M. (2014). Mediating role of intellectual capital efficiency in capital structure and financial performance of quoted banks of Pakistan. Research Journal of Finance and Accounting, 5(17), 141-150.

Belkaoui, A. and Karpik, P. G., (1989). Determinants of the Corporate Decision to Disclose Social Information. Accounting, Auditing \& Accountability Journal, 2(1).

Bonazzi, L. and Islam, S. M. N. (2007). Agency theory and corporate governance. Journal of Modelling in Management, 2(1), 7-23.

Brick, I. E., and Chidambaran, N.K. (2010). Board meetings, committee structure, and firm value. Journal of Corporate Finance, 16(4), 533-553.

Chalevas, C. and Tzovas, C. (2010). The effect of the mandatory adoption of corporate governance mechanisms on earnings manipulation, management effectiveness and firm financing. Managerial Finance, 36(3), 257-277.

Chang, W. S., and Hsieh, J. J. (2011). Intellectual capital and value creation-Is innovation capital a missing link?. International Journal of Business and Management, 6(2), 3-12.
Chen, G. Firth, M., Gao, D. N., \& Rui, O. M. (2006). Ownership structure, corporate governance, and fraud: evidence from China. Journal of Corporate Finance, 12(3), 424-448.

Cho, C. C., and Wu, C. H. (2014). Role of auditor in agency conflict and corporate governance. Chinese Management Studies, 8(3), 333-353.

Davis, J. H., Schoorman, F. D. and Donaldson, L. (1997). Toward a stewardship theory of management. Academy of Management Review, 22(1), 20-47.

Dawar, V. (2014). Agency theory, capital structure and firm performance: some Indian evidence. Managerial Finance, 40(12), 1190-1206.

Dibia, N. O., \& Onwuchekwa, J. C. (2014). An appraisal of corporate governance mechanisms and earnings management in Nigeria. International Journal of Finance and Accounting, 3(2), 49-59.

Dimitropoulos, P. (2014). Capital structure and corporate governance of soccer clubs. Management Research Review, 37(7), 658-678.

Donaldson, L., and Davis, J. H. (1991). Stewardship theory or agency theory: CEO governance shareholder returns. Australian Journal of Management, 16(1), 49-64.

Dorata, N. T. and Petra, S. T. (2008). CEO duality and compensation in the market for corporate control. Managerial Finance, 34(5), 342-353.

Eisenberg, T., Sundgren, S., \& Wells, M. T. (1998). Larger board size and decreasing firm value in small firms. Journal of Financial Economics, 48, 35-54.

Eisenhardt, K. M. (1989). Agency theory: an assessment and review. Academy of Management Review, 14(1), 57-74.

Finkelstein, S., Ham brick, D. C., and Canella, A. A. (2009). Strategic leadership; theory and research on executives, top management teams and boards. Oxford: Oxford University Press.

Gonza'lez, J. S., \& Meca, E. G. (2014). Does corporate governance influence earnings management in Latin American markets?. J Bus Ethics, 121, 419-440.

Guthrie, J., Petty, R., Yongvanich, K. and Ricceri, F. (2004). Using content analysis as a research method to inquire into intellectual capital reporting. Journal of Intellectual Capital, 5(2), 282-293.

Guthrie, J., Petty, R. and Ricceri, F. (2006). The voluntary reporting of intellectual capital: comparing evidence from Hong Kong and Australia. Journal of Intellectual Capital, 7(2), $254-271$.

Haji, A. A. and Ghazali, N. A. M. (2013). A longitudinal examination of intellectual capital disclosures and corporate governance attributes in Malaysia. Asian Review of Accounting, 21(1), 27-52. 
Hanka, G. (1998). Debt and the terms of employment. Journal of Financial Economics, 48(3), 245-282.

Hart, O. (1995). Corporate governance: some theory and implications. The Economic Journal, 105(430), 678-689.

Haspeslagh, P. (2010). Corporate governance and the current crisis. Corporate Governance: The international Journal of Business in Society, 10(4), 375-377.

Hennessey, R. (2015). When the CEO Goes Bad, the Whole Company Needs a Fresh Look. https://www.entrepreneur.com/article/250918, diakses 2 Oktober 2016.

Hidalgo, R. L., Gracía-Meca, E., and Martínez, I., (2011). Corporate governance and intellectual capital disclosure. Journal of Business Ethics, 100(3), 483-495.

Ho, C. A. and Williams, S. M. (2003). International comparative analysis of the association between board structure and the efficiency of value added by a firm from its physical capital and intellectual capital resources. The International Journal of Accounting, 38(4), 465491.

Iazzolino, G. and Laise, D. (2013). Value added intellectual coefficient (VAIC). Journal of Intellectual Capital, 14(4), 547-563.

International Advisory Services in Indonesia. (2014). The Indonesia corporate governance manual ( $1^{\text {st }}$ ed). Jakarta, Indonesia.

Jahanzeb, A., Saif-Ur-Rehman, Bajuri, N. H., Karami, M and A. Aiyoub. (2014). Trade-off theory, pecking order theory and market timing theory: A comprehensive review of capital structure theories. International Journal of Management and Commerce Innovations, 1(1), 11-18.

Jaradat, M. S. (2015). Corpoarte governance practices and capital structure: A study with special reference to board size, board gender, outside director and CEO duality. International Journal of Economics, Commerce and Management, 3(5), 264-273.

Jensen, M. C. and Meckling, W. (1976). Theory of the firm: managerial behaviour, agency costs, and ownership structure. Journal of Financial Economics, 4(4), 305-360.

Kajananthan, R. (2012). Effect of corporate governance on capital structure: Case of the Srilankan listed manufacturing company Journal of Arts, Science \& Commerce, [3(4(1)], 63-71.

Keenan, J. and Aggestam, M. (2001). Corporate governance and intellectual capital: some conceptualization. Corporate Governance: An International Review, 9(4), 259-275.

Kirkpatrick, G. (2009). The Corporate Governance Lessons from the Financial Crisis. Financial Market Trends. Paris, OECD Publication
Komite Nasional Kebijakan Governance. (2006). Pedoman umum good corporate Indonesia.

Krause, R. and Semadeni, M. (2013). Apprentice, departure, and demotion: an examination of the three types of CEO-board chair separation. Academy of Management Journal, 56(3), 805-826.

L'Huillier, B. M. (2014). What does "corporate governance" actually mean?. Corporate Governance: The International Journal of Business in Society, 14(3), 300-319.

Lehn, K., Patro, S., \& Zhao, M. (2004). Determinants of the size and structure of corporate boards: 1935-2000.

Letza, S., Kirkbride. J., Sun, X. and Smallman. C. (2008). Corporate governance theorising: limits, critics and alternatives. International Journal of Law and Management, 50(1), 1732.

Li, J., Mangena, M. and Pike, R. (2012). The effect of audit committee characteristics on intellectual capital disclosure. The British Accounting Review, 44(2), 98-110.

Lipton, M. and Lorsch, J. (1992). A modest proposal for improved corporate governance. Business Lawyer, 48, 59-77.

Lucyanda, J. and Rahmayanti, A. (2012). Pengaruh strategi bersaing dan corporate governance terhadap intellectual capital performance. JEaM, 11(1),70-82.

Maaloul, A. and Zéghal, D. (2015). Financial statement informativeness and intellectual capital disclosure. Journal of Financial Reporting and Accounting, 13(1), 66-90.

Maher, M. and Andersson, T. (1999). Corporate governance: effects on firm performance and economic growth, law and economics. Conference on Convergence and Diversity in Corporate Governance Regimes and Capital Markets, Tilburg University, Eindhoven, 4-5 November.

Makki, M. A. M. and Lodhi, S. A. (2014). Impact of corporate governance on intellectual capital efficiency and financial performance. Pakistan Journal of Commerce and Social Sciences, 8(2), 305-330.

Mili, M. and Abid, S. (2016). Do corporate bond recovery rates monitored by corporate governance mechanisms. Managerial Finance, 42(8), 830-848.

Murale, V., Jayaraj, R. and Ashrafali, (2010). Impact of Intellectual Capital on Firm Performance: A Resource Based View Using VAIC Approach. Internaltional Journal of Business Management, Economics and Information Technology, 2(2), 283-292.

Nazari, J. A. and Herremans, I. M. (2007). Extended VAIC model: measuring intellectual capital components. Journal of Intellectual Capital, 8(4), 595-609. 
Oba, V. C., Ibikunle, J. and Damagum, Y. M. (2013). The impact of board mechanisms on intellectual capital disclosures in Nigeria. Journal of Accounting and Management, 3(1), 65-80

Patel, S. A., Balic, A. and Bwakira, L. (2002). Measuring transparency and disclosure at firm-level in emerging markets. Emerging Markets Review, 3(4), 325-337.

Peraturan Otoritas Jasa Keuangan. (2014). Direksi dan dewan komisaris emiten atau perusahaan.

Pfeffer, J. (1972). Size and composition of corporate boards of directors: The organization and its environment. Administrative Science Quarterly, 17(2), 218-228

Pulic, A. (1998). Measuring the performance of intellectual potential in knowledge economy. Paper presented at the 2nd World Congress on Measuring and Managing Intellectual Capital, McMaster University, Hamilton.

Pulic, A. (2004). Intellectual capital - does it create or destroy value?, Measuring Business Excellence, 8(1), 62-68.

Rahman, R. A., \& Mohamed Ali, F. H. (2006). Board, audit committee, culture and earnings management: Malaysian evidence. Managerial Auditing Journal, 21(7), 783 - 804.

Reddy, Y. R. K. (2009). The ethics of corporate governance. International Journal of Law and Management, 51(1), 17-26.

Rubach, M. J. and Sebora, T. C. (2009). Determinants of institutional investor activism: a test of the Ryan-Schneider model (2002). Journal of Managerial Issues, 21(2), 245-261.

Saeed, S., Rasid, S. Z. A., and Basiruddin, R. (2015). The mediating role of Intellectual capital in corporate governance and the corporate performance relationship. Mediterranean Journal of Science, 6(5), 209-219.

Safieddine, A., Jamali, D. and Noureddine, S. (2009). Corporate governance and intellectual capital: evidence from an academic institution. Corporate Governance: The International Journal of Business in Society, 9(2), 146-157.

Siam, Y. I. S. A., Laili, N. H. B., \& Khairi, K. F. B. (2014). Board of directors and earnings management among Jordanian listed companies: Proposing conceptual framework. Internationnal Journal of Technical Research and Applications, 2, 01-07.
Shleifer, A. and Vishny, R. W. (1997). A survey of corporate governance. The Journal of Finance, 52(2), 737-783.

Ståhle, P., Ståhle, S. and Aho, S. (2011). Value added intellectual coefficient (VAIC): a critical analysis. Journal of Intellectual Capital, 12(4), 531-551.

Tahir, T. and Fraz, A. (2015). Human capital, capital structure, employee pay: Empirical evidence from Pakistan. Global Journal of Management and Business Research: Finance, 15(9), 19-41.

Taliyang, S. M. and Jusop, M. (2011). Intellectual capital disclosure and corporate governance structure: Evidence in Malaysia. International Journal of Business and Management, 6(12), 109-117.

Tarraf, H. (2011). The role of corporate governance in the events leading up to the global financial crisis: Analysis of aggressive risk-taking. Global Journal of Business Research, 5(4), 93105.

Vafeas, N. (1999). Board meeting frequency and firm performance. Journal of Financial Economics, 53(1), 113-142.

Vakilifard, H. R., Gerayli, M. S., Yanesari, A. M. and Ma'atoofi, A. R. (2011). Effect od corporate governance on capital structure: Case of the Iranian listed firms. European Journal of Economics, Finance and Administrative Sciences. 35, 165-172

Xie, B., Davidson III, W.N., \& DaDalt, P.J. (2003). Earnings management and corporate governance: The roles of the board and the audit committee. Journal of Corporate Finance, 9, 295-316.

Yermack, D. (1996). Higher market valuation of companies with a small board of directors. Journal of Financial Economics, 40, 185-211.

Youndt, M. A., Subramaniam, M. and Snell, S. A. (2004). Intellectual capital profiles: an examination of investments and returns. Journal of Management Studies, 41(2), 335-361.

Zéghal, D. and Maaloul, A. (2010). Analysing value added as an indicator of intellectual capital and its consequences on company performance. Journal of Intellectual Capital, 11(1), 39-60. 